\title{
The Association Between Related Party Transaction and Tax Avoidance in Indonesia
}

\author{
Putra Aryotama ${ }^{1 *}$ and Amrie Firmansyah ${ }^{2}$ \\ ${ }^{1,2}$ Sekolah Tinggi Akuntansi Negara, Tangerang Selatan, Indonesia
}

\begin{abstract}
This study aims to examine the association between related party transaction and tax avoidance in Indonesia' Non-Financial Companies. Related-party transactions, as its name implies, are transactions conducted by companies with its related parties. Meanwhile, tax avoidance is a reduction in corporate tax liability, which is conducted by the company legally. This study employs a quantitative method using linear regression analysis and uses panel data of companies listed under the Indonesian NonFinancial Companies on IDX from 2014 to 2017. The initial population that includes all listed companies in the Indonesia Stock Exchange as of March 31st, 2019, that number accounts for 626 companies. Based on the purposive sampling was conducted, this study 161 sampled companies from 2015 to 2017 (3 years), so that the total number of observed data points is 483 firm-year. The hypothesis testing suggests that related party transaction is negatively associated with tax avoidance.
\end{abstract}

Keywords: Non-Financial Companies, Related Party, Tax Avoidance

\section{Introduction}

Governments will always try to enforce tax regulation for more revenue and compliance from businesses. Businesses, on the other hand, always try to exploit loopholes in the regulation to try and minimize or even avoid paying taxes. This act by businesses to minimize or avoid paying tax can be classified as tax avoidance or tax evasion. Kirchler (2007) distinguished the difference through legal means (tax avoidance) or illegal means (tax evasion). By legal means, firms try to exploit the loopholes that exist in the tax regulation to minimize or avoid paying taxes. Otherwise, by illegal means, companies blatantly disregard the tax regulation and unlawfully avoids paying taxes altogether. Guenther et al (2017) went even further by distinguishing legal tax planning based on the fact whether management deemed it would likely be overturned by the tax authority (tax aggressiveness) or not (tax avoidance).

Tax evasion has a fundamental difficulty in that they are empirically tough to measure because of the lack of information on taxpayer compliance, the measurement of which is beyond the analysis of a typical financial statement of positive accounting research (Alm, 2012). Based on that reasoning, for this research, tax avoidance will be defined as a means by which the management of corporations can reduce, minimize, or even avoid paying taxes by legal means. One way a company's tax avoidance level can be analyzed is through its accounting information.

Previous recent research in Indonesia on tax avoidance conducted by companies have mostly been discussed about firm characteristics (size, leverage) (Wijayanti et al, 2017; Dewi \& Jati, 2014, Pajriansyah \& Firmansyah, 2017; Nurhandono \& Firmansyah, 2017), performance (earnings, profitability) (Dewi \& Noviari, 2017; Arianandini \& Ramantha 2018), management and governance (corporate governance, corporate social responsibility) (Dewi \& Jati, 2014; Wijayanti et al., 2017; Kusuma \& Firmansyah, 2018), and other external factors or political influence (Lestari \& Putri 2017, Ferdiawan \& Firmansyah, 2018). However, only a few studies have discussed on related-party transaction relates to tax avoidance. Therefore, this study aims to examine the related-party transaction on corporate tax avoidance. Companies can either

* Corresponding author. Email address : putraaryotama@gmail.com 
sell their products to related parties or other customers, which is unrelated to the company. Thus, it is interesting to investigate how these variables are related to the company's tax avoidance. The related-party transaction has been previously studied in Indonesia (Arieftiara et al (2015), Wardani \& Khoiriyah (2018), Oktavia et al (2012), Azizah \& Kusmuriyanto (2016), Sari et al (2017). However, those studies have inconsistencies in the results.

According to the political cost hypothesis as Watts \& Zimmerman (1986), the higher the political cost to the company, the more likely it is for the management to defer reported earnings from current periods to future periods. These political costs may be in the form of changes in regulation, changes in tax rates, and other changes in policy that may affect the company (Watts \& Zimmerman, 1986). This hypothesis is in line with the reason why management chooses accounting policies to minimize tax. Tax is a form of political cost imposed on the company that reduces company earnings. For that reason, managers always act opportunistically in choosing accounting policies that will lower corporate tax (tax avoidance).

There are several definitions put forward about the related-party transaction. The related-party transaction is a business deal or arrangement between two parties who are joined by a pre-existing special relationship (Kenton, 2019). This relationship can be in the form of an individual Director/Owner/Manager or as a subsidiary/associate company (Mahtani, 2018). Related-party transactions, as its name implies, are transactions done by companies with its related parties. According to PSAK 7 (Indonesia's accounting standard that regulates the disclosure of related-party transactions based on IAS 24 - Related Party Disclosure), these related-parties are individuals or entities which are related to the company in preparing the company's financial statements. Categorically, these parties might be in the form of the parent company, companies with joint control or significant influence on the reporting company, subsidiary companies, associated companies, joint ventures where the reporting company is a venture, key management of the reporting company or that of its parent, and other parties with other special relationship with the reporting company.

Transactions with related parties are a legitimate business activity. However, regulators, standard-setters, and market participants have considered them as a significant issue in business activities as they may be exploited against the interest of stakeholders. Fair price or fair trade may be called into question when related-party transactions are involved. That is why it is not surprising that RPT's exist in some highprofile corporate frauds (Bhuiyan \& Roudaki, 2018). Because of the issue on RPT, companies are required to disclose the balances and transactions done with related parties. These transactions may be in the form of sales, purchases, operating expenses, receivables, payables, and debt.

Based on agency theory, information on the related-party transaction is one of that information that, if not disclosed, may cause asymmetry information between the principal and its agent in a company. The requirement to disclose related-party transactions minimizes this agency problem. However, that does not stop managers from taking advantage of RPT to maximize their interest, as shown by Marchini et al (2018) and Mahtani (2018).

The study on the relation of the related-party transaction to tax avoidance also has inconsistencies in results. Previous studies on the related-party transaction in Indonesia uses different measures of related-party transactions: payables, receivables, debt, purchases, sales, or even operating expense (Oktavia et al, 2012; Azizah \& Kusmuriyanto, 2016; Sari et al, 2017) and obtains different results based on its measurement. This research uses only related-party sales as a measure of the relatedparty transaction to reflect supplier-customer relations better.

To control for extraneous effect, this research will also employ several control variables. These control variables are variables that have been proven to relate to tax avoidance based on previous studies. Those control variables are profitability (Dewi \& Noviari, 2017; Arianandini \& Ramantha, 2018; Darmawan \& Sukartha, 2014), 
leverage (Lestari \& Putri, 2017; Dewi \& Noviari, 2017) and size (Darmawan \& Sukartha, 2014; Wijayanti et al., 2017; Dewi \&Noviari, 2017).

This research is very relevant in Indonesia because businesses in Indonesia, as in any other country, also conducts the related-party transaction. Furthermore, requirements by accounting standards for companies to disclose related-party transactions shows how vital this information is in Indonesia. By answering the call of Hanlon \& Heitzman (2010) for more studies on the determinants of tax avoidance, this study investigates how the related-party transaction of the company is related to tax avoidance. This study also contributes earlier research on tax avoidance in Indonesia by providing more evidence on the determinants of tax avoidance (related-party transaction).

\section{Hypothesis Development}

Related-party transactions are often misused by company management to alter and influence reported earnings (Mahtani, 2018). This short-term high earning is preferable for managers in pursuing their self-interest (higher bonus and more recognition). Alteration and influence of reported earnings by managers for self-gain is an exhibit of the agency problem that exists between managers that act as agents with its principal (equity owners). However, this problem can be alleviated through the implementation of good quality corporate governance, as shown by Marchini et al (2018).

Previous research by Park (2018) found that Korean companies that belong in a business group perform tax avoidance by using related-party transactions. Companies in a business group can take advantage of group relations to conduct tax avoidance to minimize corporate tax at the business group level. In Indonesia, a similar result was documented by Azizah \& Kusmuriyanto (2016): the bigger the size of the related-party transaction, the more the company is engaging tax avoidance. However, when examining specific industry - manufacturing companies in Indonesia, by Oktavia et al. (2012), the relation is found to be in the opposite direction: higher related-party transaction leads to less tax avoidance. The findings in Indonesia is still inconsistent.

Companies have incentives to minimize tax to increase profitability. A business group minimizes the total tax burden at the group level through income shifting between companies in the group. It is conducted by shifting income from companies with high tax burden to its related company with a low tax burden in a business group. As long as the net change from both the company that reduces taxable income and the company whose taxable income increases is negative (total decrease), those companies would keep shifting their incomes. This income shifting is conducted through relatedparty transactions. A multinational business group that operates in different jurisdictions shifts income from companies that reside in a high tax-rate country to companies that reside in a low tax-rate country or tax-haven country. A business group that only operates in one jurisdiction can also gain by shifting income from one company to another. In the same jurisdiction that may only have a single tax rate, income is shifted based on tax strategy, net operating loss, and tax credits.

H1: Related-party transaction is positively related to tax avoidance

\section{RESEARCH METHODOLOGY}

\subsection{Sample Selection}

This research is quantitative, specifically causal-comparative. The data used for this experiment is secondary data. Secondary data are data that have been collected by other parties from its primary source. In this case, the data being used is extracted from the financial statement of each of the object companies. Financial statements are data about the company which has been extracted and compiled by the company itself.

Furthermore, this research uses data panel, which is data from individual companies (cross-sectional) across different years (time-series). The population of data for this research is the financial data for the period of 2015 to 2017 of companies that 
are listed in IDX after 2010. The period (2015 to 2017) is selected to coincide with the enactment of PSAK 46 (2014 revision) which require firms to separate tax that is imposed on a measure of pretax income (income tax expense) and tax that is imposed on measures other than pretax income (final tax expense). The separation is crucial to measure tax avoidance in this research. Furthermore, this study also excludes companies that fall into the category of Financial companies according to IDX classification (banks, financial institutions, insurance, etc.) from the sample. Also, some companies were found to not have a complete financial statement data either in one or many financial years were eliminated as well as companies with negative pretax income.

\subsection{Research Variables Dependent Variable}

This study employs Discretionary Permanent BTD (DTAX) as a tax avoidance proxy, which follows Frank et al (2009) and Rachmawati \& Martani (2014). By controlling for non-discretionary items of the permanent difference between book income and taxable income, this measure of tax avoidance captures the non-conforming tax avoidance. The original equation from Frank et al. (2009) is adjusted by Rachmawati and Martani (2014), as presented in equation (1) to conform to the Indonesian context. In the equation, the permanent difference is controlled for goodwill and other intangible assets, change in loss carryforwards, and the non-discretionary permanent difference that persist through time.

$$
\text { PERMDIFF }_{\text {it }}=\alpha_{0}+\beta_{1} \text { INTANG }_{i t}+\beta_{2} \Delta \text { NOL }_{i t}+\beta_{3} \text { LAGPERM }_{\text {it }}+\varepsilon_{i t}
$$

Where:

PERMDIFF $_{i t}=$ Total BTD less temporary BTD for firm $\mathrm{i}$ in year $\mathrm{t}:\left[\mathrm{BI}_{\mathrm{it}}-\right.$ $\left.\left(\mathrm{CTE}_{\mathrm{it}} / \mathrm{STR}_{\mathrm{it}}\right)\right]-\left(\mathrm{DTE}_{\mathrm{it}} / \mathrm{STR}_{\mathrm{it}}\right)$

$\mathrm{BI}_{\mathrm{it}} \quad=$ Pretax income for firm $\mathrm{i}$ in year $\mathrm{t}$

$\mathrm{CTE}_{\mathrm{it}} \quad=$ Current tax expense for firm $\mathrm{i}$ in year $\mathrm{t}$

DTE $_{\text {it }} \quad=$ Deferred tax expense for firm $\mathrm{i}$ in year $\mathrm{t}$

STR $_{\text {it }} \quad=$ The statutory tax rate for firm $\mathrm{i}$ in year $\mathrm{t}$

INTANG $_{\text {it }}=$ Goodwill and other intangible assets for firm $\mathrm{i}$ in year $\mathrm{t}$

$\triangle \mathrm{NOL}_{\mathrm{it}} \quad=$ Change in net operating loss for firm $\mathrm{i}$ in year $\mathrm{t}$

LAGPERM $_{i t} \quad=$ One-year lagged PERMDIFF for firm $\mathrm{i}$ in year $\mathrm{t}$

$\varepsilon_{\mathrm{it}} \quad=$ The permanent discretionary difference for firm $\mathrm{i}$ in year $\mathrm{t}$

This research, however, further adjusts the equation from Rachmawati \& Martani (2014) as presented in equation (2) to control for final tax. The final tax is regulated for specific industries, and companies cannot freely choose whether to apply the final tax. On the other hand, companies in those specific industries must accept and comply with the final tax policy. Final tax is a non-discretionary item that must also be controlled for when determining permanent discretionary difference.

PERMDIFF $_{\text {it }}=\alpha_{0}+\beta_{1}$ INTANG $_{\text {it }}+\beta_{2} \Delta$ NOL $_{i t}+\beta_{3}$ LAGPERM $_{\text {it }}+\beta_{3}$ FINAL $_{\text {it }}+\varepsilon_{\text {it }}$

Where: FINAL $_{i t}=$ Final tax for firm $\mathrm{i}$ in year $\mathrm{t}$

\section{Independent Variable}

This study employs a related-party transaction as an independent variable. Previous research on related-party transactions has measured related-party transactions based on combinations of related-party receivables, purchases, debt, or sales (Park, 2018; Azizah \& Kusmuriyanto, 2016; Oktavia et al, 2012). Because this research studies business decisions related to strategy, customer, and product, the related-party transaction is measured based on related-party sales. It is the ratio of company sales to related party over total company sales for the company $\mathrm{i}$ in year t.

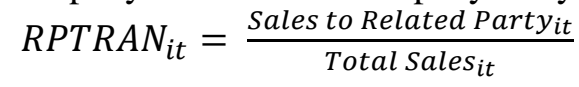




\section{Control Variables}

This research uses three controlled variables that have been proven to affect tax avoidance in previous studies: size, profitability, and leverage of the company (Darmawan \& Sukartha, 2014; Arianandini \& Ramantha, 2018; Lestari \& Putri, 2017; Dewi \& Noviari, 2017; Lionita \& Kusbandiyah, 2017). Profitability is measured using the return on asset (ROA). Company size uses the natural logarithm of a total company asset, while leverage is measured by the ratio of total company liabilities to total company assets.

$$
\begin{gathered}
R_{\text {O }} A_{i t}=\frac{{\text { Net } \text { Income }_{i t}}_{\text {Total Assets }_{i t}}}{\text { SIZE }_{i t}=\ln \left(\text { Total Assets }_{i t}\right)} \\
\text { LEVERAGE }_{i t}=\frac{\text { Total Liabilities }_{i t}}{\text { Total Assets }_{i t}}
\end{gathered}
$$

The research model in this study, as follows:

$$
\text { TAV }_{i t}=\alpha_{0}+\beta_{1} \text { RPTRAN }_{\text {it }}+\beta_{2} \text { SIZE }_{i t}+\beta_{3} \text { ROA }_{i t}+\beta_{4} \text { LEVERAGE }_{i t}+\varepsilon_{i t}
$$

Where:

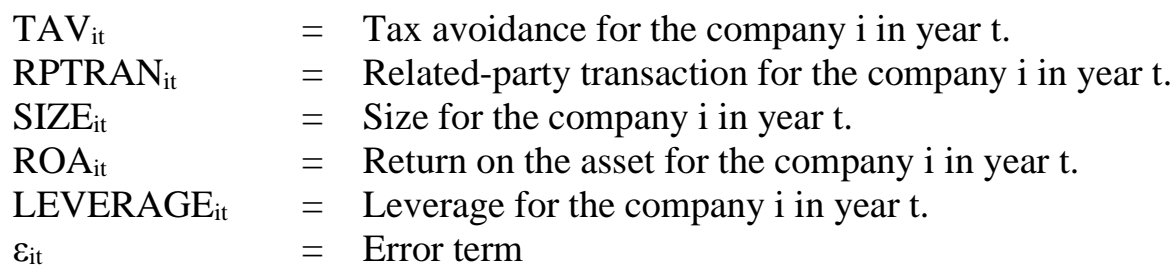

\section{RESULTS AND DISCUSSION}

Based on purposive sampling was conducted, this study examines obtain 161 sampled companies from 2015 to 2017 (3 years). Thus, the total number of observations is 483 firm-year. The descriptive statistical analysis in this study is described by using the mean, maximum, minimum (minimum), and standard deviation (Std. Dev.). The summary of the results of descriptive statistics on the variables data in this study presented in Table 1

Table 1 Descriptive Statistics

\begin{tabular}{lccccc}
\hline & TAV & RPTRAN & ROA & SIZE & LEV \\
\hline Mean & $1.08 E-17$ & 0.112516 & 0.071762 & 28.71764 & 0.437264 \\
Median & -0.000917 & 0.004100 & 0.052478 & 28.68990 & 0.432955 \\
Maximum & 0.337142 & 1.000000 & 0.526704 & 33.19881 & 0.947561 \\
Minimum & -0.447181 & 0.000000 & -0.097143 & 24.28605 & 0.007623 \\
Std. Dev. & 0.045551 & 0.224412 & 0.076683 & 1.707263 & 0.181582 \\
Observations & 483 & 483 & 483 & 483 & 483 \\
\hline
\end{tabular}

Furthermore, the results of regression model selection tests (chow test, Lagrange multiplier test, Hausman test) suggest that the most appropriate regression model in this research is a fixed-effect model (FEM). The result of equation model regression as follows:

Table 2 Equation Model Regression Test Results

\begin{tabular}{cccccc}
\hline Variable & Coeff. & Std. Error & t-Statistic & Prob. & \\
\hline C & -0.1005 & 0.0144 & -6.9401 & 0.000 & $* * *$ \\
RPTRAN & -0.0181 & 0.0080 & -2.2496 & 0.025 & $* * *$ \\
ROA & 0.6186 & 0.0279 & 22.163 & 0.000 & $* * *$ \\
SIZE & 0.0019 & 0.0004 & 4.5334 & 0.000 & $* * *$ \\
LEVERAGE & 0.0019 & 0.0101 & 0.1967 & 0.844 & \\
R-squared & 0.9009 & & & \\
Adj. R-squared & 0.8498 & & & \\
F-statistic & 17.635 & & & \\
Prob(F-statistic) & 0.0000 & & &
\end{tabular}




\section{Discussion on the relation of the related-party transaction to tax avoidance}

From the hypothesis examination, this study suggests that related-party transaction is negatively related to tax avoidance. Thus, the hypothesis is rejected. Related-party transactions are transactions that are conducted by the company with individuals or entities who are related in some way to the reporting company. There are several categories of transactions. However, this research only specifies the sales of goods and services to related parties. Related-party transaction (RPTRAN) is measured by the ratio of the number of sales to related-party divided by total company sales. Based on the agency theory, managers protect their self-interest. According to previous studies, companies who engage in related-party transactions tend to alter and influence reported earnings at the expense of investors. However, the relation can be weakened when good corporate governance is introduced.

Because tax is a form of cost to the company, companies have incentives to minimize tax to maximize after-tax returns. In a business group, companies engage in tax avoidance through income shifting using related-party transactions. By shifting income, they may reduce the total tax paid as a business group. That is done by shifting income from high-tax burden companies to low tax burden companies to take advantage of lower tax rates (for multinational companies which operate in different jurisdictions) or to take advantage of specific beneficial tax strategies, companies running operating losses, and tax credits (for companies in the same jurisdiction). Because of this, companies that have high related-party transactions are more likely to engage in tax avoidance activities.

However, that is not the case in Indonesia. This research found that related-party transaction is negatively related to tax avoidance. The higher the related-party transaction a company has, the lower the tax avoidance. Although business groups prefer to shift income from companies with high tax burdens to companies with low tax burdens, companies in Indonesia would slightly shift income in the same jurisdiction rather than across borders. Companies in Indonesia would slightly shift income in the same jurisdiction to take advantage of specific tax strategies than shift income across jurisdictions to take advantage of different (lower) tax rates. According to Nurhidayati and Fuadillah (2018), transfer pricing aggressiveness is not related to tax haven utilization in Indonesia. Companies would instead engage with thin capitalization than transfer pricing to shift income to tax haven countries. Based on that research, multinational companies in Indonesia do not prefer to shift income using related-party sales between jurisdictions to take advantage of lower tax rates (in this case, even tax haven countries). Companies may find that dealing with transfer pricing across different borders may pose more risk to the company than transfers within the borders.

The fact that this research uses the abnormal book-tax difference as a measure of tax avoidance, and that final tax is taken into account as a non-discretionary item to arrive at the residual for abnormal BTD, is another evidence that companies prefer to engage in related-party sales within Indonesia to shift income. Based on the result of this research, higher related-party sales mean lower abnormal BTD. Because the final tax is determined as non-discretionary items that explain BTD, lower abnormal BTD may be caused by a high amount of final tax. Therefore, companies are suspected of shifting income to companies which are subject to final income tax or companies with special incentives. Because the final tax is only accounted for once, this could eliminate some risk of uncertainty from income tax in companies.

The findings of this research contradict the findings of Park (2018) in Korea. Park (2018) found that the related-party transaction is positively related to tax avoidance. The more a company is engaged in related-party transactions, the more likely also that it would engage in tax avoidance. The study by Park (2018) uses a sample of South Korean companies. The difference of result between this research and that of Park (2018) may, in part, be because companies in South Korea have different tax regulations than in Indonesia. In South Korea, there is no final income tax, like the 
one being applied in Indonesia to the knowledge of the researcher. Because of this, companies in South Korea may opt to shift their income across borders to countries with lower tax rates or tax havens.

This research also contradicts with research in Indonesia by Azizah and Kusmuriyanto (2016) and Oktavia et al. (2012). Similar to Park (2018), they found that the related-party transaction is positively related to tax avoidance. Azizah and Kusmuriyanto (2016) use related-party debt to measure related-party transactions and BTD to measure tax avoidance. On the other hand, Oktavia et al. (2012) use relatedparty debt and related-party receivable to measure related-party transactions and ETR to measure tax avoidance. The use of BTD and ETR in both of those research to measure tax avoidance may not capture the effect of final tax as a non-discretional permanent difference, unlike the use of the measurement used in this research.

The related-party transaction is negatively related to tax avoidance in Indonesia. This relation could be attributed to the fact that companies in Indonesia prefer to shift income in the same jurisdiction (within Indonesia) rather than across borders to a low tax country or even a tax haven country through transfer pricing. Because of the existence of final tax regulation, companies are incentivized to shift income to those companies that are subject to the final tax. Final tax, as the name implies, are final. It is not accounted for again in determining income tax payable for the fiscal year. Hence, there is certainty in the tax paid. Also, the rates of final tax in Indonesia is considered low, ranging from $0.1 \%$ to $6 \%$.

\section{CONCLUSION}

The hypothesis examination suggests that the related-party transaction is negatively related to tax avoidance. There are two reasons to explain this result. First, companies in Indonesia would slightly shift income in the same jurisdiction to take advantage of specific tax strategies than shift income across jurisdictions to take advantage of different (lower) tax rates. Companies may find that dealing with transfer pricing across different borders may pose more risk to the company than transfers within the borders. Second, the fact that this research uses the abnormal book-tax difference as a measure of tax avoidance, and that final tax is taken into account as a non-discretionary item to arrive at the residual for abnormal BTD, is another evidence that companies prefer to engage in related-party sales within Indonesia.

However, this research has limitations. Based on purposive sampling was conducted, this study only uses a sample of 161 companies in three years. A much bigger sample with more than 161 companies with a period of more than three years would reduce statistical error. This research also uses a measure of tax avoidance that has never been applied in previous studies. Therefore, future research may extend the period of research object to add more observations and capture more comprehensively the relation of the related-party transaction on tax avoidance. Also, the future study may examine the relation of the related-party transaction on tax avoidance in the finance industry.

Related-party transaction (through sales) is a good indication of whether a company is engaging in tax avoidance or not. Because the ratio of tax accountrepresentative and tax auditor to the number of taxpayers is small, it is quite hard to determine the optimum choice of which taxpayer to scrutinize and supervise (by account representative) and which to audit (by auditors). To solve that problem, the Indonesian Tax Authority has started to implement risk-based audits to assist in determining which taxpayers need to be audited based on the risk of taxpayer's noncompliance.

The related-party transaction and even tax avoidance involve certain risks and uncertainty for the company. Based on this research, investors have a more comprehensive look at a company to determine whether or not to invest in a company based on company risk and the investor's risk profile. Investors may look at the related- 
party transaction on more information about its inherent risk and how it relates to efforts by the company to lower corporate tax.

\section{References}

Alm, J. (2012). Measuring, explaining, and controlling tax evasion: lessons from theory, experiments, and field studies. International Tax and Public Finance, 19(1), 54-77.

Arianandini, P. W., \& Ramantha, I. W. (2018). Pengaruh Profitabilitas, Leverage, Dan Kepemilikan Institusional Pada Tax Avoidance. E-Jurnal Akuntansi Universitas Udayana, 22(3), 2088-2116.

Arieftiara, D., Utama, S., Wardhani, R., \& Ning, R. (2015). Analisis pengaruh strategi bisnis terhadap penghindaran pajak, bukti empiris di Indonesia. Simposium Akuntansi Nasional XVIII, 18(1), 1-27.

Azizah, N., \& Kusmuriyanto (2016). The effect of related party transaction, leverage, commissioners, and directors compensation on tax aggressiveness. Accounting Analysis Journal, 5(4), 307-16.

Bhuiyan, M. B. U., \& Roudaki, J. (2018). Related party transactions and finance company failure: New Zealand evidence. Pacific Accounting Review, 30(2), 199-221.

Darmawan, I. G. H., \& Sukartha, I. M. (2014). Pengaruh penerapan corporate governance, leverage, return on assets, dan ukuran perusahaan pada penghindaran pajak. E-Jurnal Akuntansi Universitas Udayana, 9(1), 143-61.

Dewi, N. L. P., \& Noviari, N. (2017). Pengaruh ukuran perusahaan, leverage, profitabilitas dan corporate social responsibility terhadap penghindar pajak (tax avoidance). E-Jurnal Akuntansi Universitas Udayana, 21(1), 830-59.

Dewi, N. N. K., \& Jati, I. K. (2014). Pengaruh karakter eksekutif, karakteristik perusahaan, dan dimensi tata kelola perusahaan yang baik pada tax avoidance di Bursa Efek Indonesia. E-Jurnal Akuntansi Universitas Udayana, 6(2), 249-60.

Ferdiawan, Y., \& Firmansyah, A. (2017). Pengaruh political connection, foreign activity, dan real earnings management terhadap tax avoidance. Jurnal Riset Akuntansi Dan Keuangan, 5(3), 1601-1624

Frank, M. M. Lynch, L. J., \& Rego, S. O. (2009). Tax reporting aggressiveness and its relation to aggressive financial reporting. The Accounting Review, 84(2), 46796.

Guenther, D. A., Matsunaga, S. R., \& Williams, B. M. (2017). Is tax avoidance related to firm risk? The Accounting Review, 92(1), 115-36.

Hanlon, M., \& Heitzman, S. (2010). a review of tax research. Journal of Accounting and Economics, 50(2-3), 127-78.

Kenton, W. (2019). Related-Party Transaction. https://www.investopedia.com/terms/r/related-partytransaction.asp.

Kirchler, E. (2007). The economic psychology of tax behaviour. New York: Cambridge University Press.

Kusuma, C. A., \& Firmansyah, A. (2018). Manajemen laba, corporate governance, kualitas auditor eksternal dan agresivitas pajak. Jurnal Tekun, 8(1), 108-123.

Lestari, G. A. W, \& Putri, I. G. A. M. A. D. (2017). Pengaruh corporate governance, koneksi politik, dan leverage terhadap penghindaran pajak. E-Jurnal Akuntansi Universitas Udayana, 18(3), 2028-54. 
Lionita, A., \& Kusbandiyah, A. (2017). Pengaruh corporate social responsibility, profitability, leverage, dan komisaris independen terhadap praktik penghindaran pajak pada perusahaan yang terdaftar Di BEI. Kompartemen: Jurnal Ilmiah Akuntansi, XV(1), 1-11.

Mahtani, U.S. (2018). Related party transactions in India and their impact on reported earnings. The Journal of Developing Areas, 53(1), 165-78.

Marchini, P. L., Mazza, T., \& Medioli, A. (2018). Related party transactions, corporate governance, and earnings management. Corporate Governance (Bingley), 18(6), $1124-46$.

Nurhandono, F., \& Firmansyah, A. (2017). Pengaruh lindung nilai, financial leverage, dan manajemen laba terhadap agresivitas pajak. Media Riset Akuntansi, Auditing \& Informasi, 17(1), 31-52

Nurhidayati, \& Fuadillah, H. (2018). The influence of income shifting incentives towards the tax haven country utilization: case study on the companies listed in Indonesian Stock Exchange. Jurnal Akuntansi Dan Keuangan, 20(1), 27-38.

Pajriansyah, R., \& Firmansyah, A. (2017). Pengaruh leverage, kompensasi rugi fiskal dan manajemen laba terhadap penghindaran pajak. Keberlanjutan, 2(1), 431-459.

Park, S. (2018). Related party transactions and tax avoidance of business groups. Sustainability, 10(10), 1-14.

Rachmawati, N. A. \& Martani, D. (2014). Pengaruh large positive abnormal book-tax differences terhadap persistensi laba. Jurnal Akuntansi Dan Keuangan Indonesia, 11(2), 120-37.

Sari, D. K., Utama, S., Rossieta, H. (2017). Tax avoidance, related party transactions, corporate governance, and the corporate cash dividend policy. Journal of Indonesian Economy and Business Volume, 32(3), 190-208.

Oktavia, Kristanto, S. B., Subagyo, \& Kurniawati, H. (2012). Transaksi hubungan istimewa dan pengaruhnya. Jurnal Akuntansi,12, 701-16.

Wardani, D. K., \& Khoiriyah, D. (2018). Pengaruh strategi bisnis dan karakteristik perusahaan terhadap penghindaran pajak. Akuntansi Dewantara, 2(1), 25-36.

Watts, R. L., \& Zimmerman, J. L. (1986). Positive Accounting Theory. Englewood Cliffs, N.J.: Prentice-Hall.

Wijayanti, A., \& Chomsatu, Y. (2017). Pengaruh karakteristik perusahaan, GCG dan CSR terhadap penghindaran pajak. Journal of Economic and Economic Education, 5 (2), 113-27. 